\section{Byelorussian Chronicle}

EVENTS IN BYELORUSSIA

On 28th February the Jakub Kołas Institute of Linguistics of the Byelorussian Academy of Sciences held a commemorative meeting to mark the $85 \mathrm{th}$ anniversary of the birth of the outstanding Byelorussian scholar and political leader Branisłaŭ Taraškievič (1892-1938). As the author of the first grammar of literary Byelorussian (the first edition of which appeared in 1918), the basis of all subsequent grammars, Taraškievič made a lasting contribution to the development of Byelorussian language. $\mathrm{He}$ spent periods of time in both Polish and Soviet prisons, and died in the latter in undisclosed circumstances.

A conference entitled 'Problems of literature in the modern age' was held on 21-22 April in Minsk under the auspices of the Janka Kupała Institute of Literature of the Byelorussian Academy of Sciences.

*

The third conference on the subject 'Typology of Slavic literatures and interrelation of Slavic languages' was held on 2-3 December at the Institute of Education in Minsk.

The Union of Byelorussian Artists held their 10th Congress on 16-17 February in Minsk.

An evening in honour of the playwright Andrej Makajonak was held on 8 February at the Janka Kupała Theatre in Minsk. The actors of the theatre showed excerpts from the author's best known comedies, such as Lavonicha na arbicie, Tabletka pad jazyk and others.

The premiere of the new play by Ivan Samiakin, I zmoŭkli ptuški (The birds fell silent), was staged by the Janka Kupała Theatre in Minsk during its autumn season.

The beginning of the year 1977 saw the inauguration of 'literary evenings' held every Friday at the Writers' House in Minsk. At the first evening, which was held on 7 January, those present were regaled with a selection of works of Byelorussian poets... in Russian translation.
An evening of modern lyric poetry was held in April in Minsk, with the participation of several poets such as Aleh Łojka, Ryhor Baradulin, Vasil Zujonak, Alaksiej Zarycki, Piatruś Makal, Raman Tarmoła, Hienadź Buraŭkin, Kastuś Ćvirka, Halina Karžanieŭskaja and others.

*

A discussion on the fate of the socalled 'Vierchni horad' (Upper town), the most ancient part of Minsk, which is threatened by demolition because of new plans for the redevelopment of that part of the city, took place in the literary weekly Litaratura $i$ mastactva during the period Dec. 1976 May 1977. All correspondents writers, artists, scientists and workers, - expressed their deep concern about the attitude of the authorities towards the ancient monuments of the Byelorussian capital, and were unanimous in demanding their preservation.

The great Byelorussian poet Maksim Bahdanovič (1891 - 1917) left Byelorussia at the age of 4 , and did not see his native country again till 1911, when he spent his summer vacations partly in Vilna and partly in the village of Rakucioǔščyna in the Maładziečna district. This visit had a considerable effect on all his subsequent work. Now the inhabitants of Rakucioǔščyna have erected a memorial to commemorate the poet's sojourn in their village.

Byelorussian literature lost in 1977 the poetess Jeŭdakija Łoś (b. 1929), the playwright Arkadź Maŭzon (b. 1918) and the novelist Uladzimir Karpaŭ (b. 1912). All three began to write after the last war. Karpaŭ's best works are the trilogy of novels Za hodam hod, Viasiennija liüni and Sotaja mazadość, the action of which extends for over two decades in postwar Minsk. Several plays by Maŭzon deal with moral problems in presentday society. Jeŭdakija Łoś was a lyric poet of considerable talent, although the general effect of her works was often ruined by an exaggerated conformity to the official political line.

Three outstanding Byelorussian actors also died in 1977: Lidija Ržec- 
kaja (b. 1899), Cimafiej Siariejčyk (b. 1899) and Pavieł Małčanaŭ (b. 1902).

\section{EVENTS ABROAD}

The Byelorussian Institute of Arts and Sciences in New York held a conference on 12 February at Seaton Hall University to commemorate the 25 years of its existence. Among the numerous participants there were several members of the Institute, such as Dr. V. Tumaš (President), Prof. A. Adamovič, Dr. J. Kipiel, Dr. J. Zaprudnik, Dr. V. Arechva, Dr. S. Stankievič and others, as well as many guests, among them Prof. G. Shevelov (Columbia University), Prof. T. Bird (Queen's College), Dr. P. Grimsted (Harvard University).

The Second Byelorussian National Heritage Festival took place on 21 May in the Garden State Arts Center, New Jersey (USA). The rich programme of lectures, exhibitions and artistic events attracted to the Festival a large number of visitors and contributed to make it a great success.

The Byelorussian poet Anatol Viarcinski, who was in New York as a member of the Byelorussian delegation to the General Assembly of the United Nations, gave a recital of his poetry on 7 December at Queen's College, New York City University. The recital was organised on the initiative of Prof. T. Bird.

The First Convention of Byelorussians in Australia took place in Sydney on 31 December 1976 - 2 January 1977.

A Byelorussian poet living in Poland, Viktar Śvied, was elected a member of the Polish Writers' Union.

An evening of Byelorussian literature was held in Moscow on 21 March with the participation of several Byelorussian writers, such as Ivan Šamiakin, Arkadź Kulašoŭ, Ivan $\mathrm{Na}$ vumienka, Nił Hilevič, Ryhor Baradulin, Piatruś Makal, Viera Viarba, Vasil Zujonak and others.

A reception in honour of Prof, A. B. McMillin to mark the publication of his work, A History of Byelorussian
Literature, was given on 21 May by the Anglo-Byelorussian Society jointly with the Association of Byelorussians in Great Britain at the Francis Skaryna Library in London.

The following papers were read during the 12th Lecture course on Byelorussian Culture, organised by the Anglo-Byelorussian Society at the Francis Skaryna Library in London during the academic year 1977-78: 'Maksim Bahdanovič and the development of modern Byelorussian poetry' (Prof. A. B. McMillin); 'Byelorussian postage stamps, postal vignettes and labels (1918-1978)' (G. Picarda); 'The terminology regarding Byelorussia from the 15th to the 18th century' (A. Nadson); 'Byelorussian orthography from 1933 to the present day' (P. Mayo); 'Oriental borrowings in the language of Byelorussian Tatars' (S. Akiner); 'Sixty years of the Byelorussian National Republic in historical perspective' (J. Dingley).

*

Archimandrite Leŭ Haroška, Byelorussian Catholic priest and member of the Congregation of Marian Fathers, died on 28 July in Paris, aged 66 . He was one of the most distinguished members of the Byelorussian Catholic community. During the years 1946-58 he lived in Paris, where he edited the religious journal Božym šlacham, founded by him in 1947. From 1960 to 1970 he was Rector of the Byelorussian Catholic Mission in London. During that time he took a keen interest in the activities of the Anglo-Byelorussian Society, and was a contributor to the first issues of $J B S$. During the last years of his life he was director of the Byelorussian section of the Vatican Radio. Archimandrite Haroška was an outstanding scholar with a particular interest in Church history, as well as a keen bibliophile. His considerable book collection formed part of the initial holdings of the Francis Skaryna Library.

The Byelorussian historian Ivan Lubačko died in Murray (USA) on 20 July. After the last war he settled in the USA, where he was professor of history at Murray State University. Prof. Lubačko was the author of the book Belorussia under Soviet Rule, 1917-1957 (publ. in 1972). 